Stephen H. Rolbin MDCM FRCPC,

Stephen H. Halpern MD FRCPC,

Bernard M. Braude MB BCH DA(SA) FFA(SA) FRCPC, Deena Kapala RN, Robin Unger, Shyam Radhakrisnan

\title{
Fluid through the epidural needle does not reduce complications of epidural catheter insertion
}

y avoir d'avantage à injecter de liquide dans l'espace épidural \begin{abstract}
trauma or nerve root irritation. The purpose of this study was to assess whether the injection of small amounts of fluid through the Tuohy needle prior to catheter insertion reduced the incidence of these and other minor complications. Two hundred patients in labour, requesting epidural analgesia, were randomly assigned to one of three groups: Group I - the catheter was inserted without previous injection of fluid; Group $I I-3 \mathrm{ml}$, 1.5 per cent lidocaine hydrochloride was injected through the needle prior to catheter insertion; Group III $-3 \mathrm{ml}$, saline was injected prior to catheter insertion. There were no differences among the groups in the incidence of blood vessel trauma or paraesthesiae. We conclude that there is no advantage in injecting of fluid routinely into the epidural space prior to catheter insertion.
\end{abstract}

Epidural catheter insertion may be associated with blood vesse

Un cathéter qui pénètre dans l'espace épidural peut irriter une racine nerveuse ou transpercer un vaisseau. Nous avons essayé de diminuer l'incidence de ces complications en injectant du liquide dans l'aiguille de Tuohy avant d'y introduire le cathéter. Nous avons randomisé en trois groupes, 200 candidates à l'analgésie épidurale pendant le travail. Dans le groupe I, nous insérions le cathéter sans injection préalable alors que dans les groupes II et III, nous injections respectivement $3 \mathrm{ml}$ de lidocaïne d 1.5 pour cent et $3 \mathrm{ml}$ de soluté physiologique avant de passer le cathéter. Nous n'avons pu démonirer quelque différence que ce soit entre les groupes quant à l'incidence de traumatisme vasculaire ou de paresthésie. II ne semble donc pas

\section{Key words}

ANAESTHESIA: obstetric;

ANAESTHETIC TECHNIQUES: epidural complications; EQUIPMENT: catheters, epidural.

From the Department of Anaesthesia, Mount Sinai Hospital and Women's College Hospital, University of Toronto.

Address correspondence to: Dr. S. Rolbin, Department of Anaesthesia, Mount Sinai Hospital, 600 University Avenue, Toronto, Ontario M5G 1 X5. avant d'y introduire un cathéter.

Continuous epidural analgesia is commonly used for pain relief in labour. Anaesthetists may inject a small amount of fluid through the epidural needle prior to insertion of the catheter in order: (1) to separate the epidural space tissue planes and permit easier passage of the catheter; (2) to reduce the time needed to produce analgesia; and (3) to act as a test dose to rule out subarachnoid or intravenous placement of the needle.'

The insertion of an epidural catheter may be associated with nerve root irritation. When the catheter is passed without prior administration of fluid through the epidural needle the incidence of transient paraesthesiae may be as high as 49 per cent. ${ }^{2-4} \mathrm{~A}$ preliminary study demonstrated a reduction in the incidence of paraesthesiae from 49 to 32 per cent when local anaesthetic was injected through the epidural needle prior to epidural catheter insertion. ${ }^{3}$ It is not known whether the local anaesthetic might prevent paraesthesiae by decreasing its perception or by the physical presence of fluid causing displacement of the nerves.

Similarly, blood vessel trauma can occur with insertion of the epidural catheter. The incidence may be as high as 12 per cent; ${ }^{2}$ but the prior injection of the small volume of fluid through the epidural needle does not significantly decrease this. ${ }^{3}$ The purpose of this study was to determine the validity of our preliminary data and to differentiate between the possible mechanisms of reduction in the incidence of parasthesiae. In addition, we wished to determine if transient paraesthesiae were associated with prolonged neurological deficits.

\section{Methods}

The study was approved by the Human Subjects Review Committee at the University of Toronto and informed consent was obtained from all participants. 
Two hundred patients, who requested epidural analgesia for the first stage of labour, were selected and randomly assigned to one of three groups:

\section{Group I}

The epidural catheter was placed through the needle prior to the administration of any fluid. After a negative aspiration test, $3 \mathrm{ml}, 1.5$ per cent lidocaine was injected through the catheter. If there was no evidence of intravascular or intrathecal injection, $9 \mathrm{ml}, 0.25$ per cent bupivacaine were given three minutes later.

\section{Group II}

$3 \mathrm{ml}, 1.5$ per cent lidocaine hydrochloride was injected through the needle prior to catheter insertion. After a negative aspiration test, an additional $3 \mathrm{ml}, 1.5$ per cent lidocaine was given through the catheter followed by 6 $\mathrm{ml}, 0.25$ per cent bupivacaine three minutes later.

\section{Group III}

$3 \mathrm{ml}$ of preservative-free normal saline was injected through the needle prior to epidural catheter insertion. After a negative aspiration test, $3 \mathrm{ml}, 1.5$ per cent lidocaine was given through the catheter followed three minutes later by $6 \mathrm{ml}, 0.25$ per cent bupivacaine.

In all patients the epidural space was identified with the loss of resistance technique using less than $2 \mathrm{ml}$ of air through a 16- or 17-gauge Tuohy needle. A 19-gauge Portex nylon epidural catheter (model No. 389300), which has a blunt end and three side holes near the catheter tip, was passed. The catheters were advanced five centimeters into the epidural space. The procedure was done by senior anaesthesia residents, fellows or staff.

An independent observer was present to ensure uniformity of technique and to record patient height, weight, parity, gestational age, cervical dilatation, the ability of the anaesthetist to pass the catheter on the first attempt without manipulation, the appearance of frank blood in the catheter, and the presence of paraesthesiae with or without involuntary maternal leg movement. The catheter was observed for blood return both passively and after the application of negative pressure. If the patient did not volunteer any symptoms or signs of paraesthesiae, she was then asked directly by the observer.

Twenty minutes after the insertion of the epidural needle, the quality of pain relief and degree of motor blockade were assessed. The patient was asked if she had complete pain relief, some pain but was satisfied, or unsatisfactory pain relief. More local anaesthetic was given at this time if necessary. Motor blockade was tested objectively according to the following criteria: (1) nil if there was free movement of legs and feet; (2) partial if patient was just able to flex knees; (3) almost complete if
TABLE I Demographic data

\begin{tabular}{|c|c|c|c|}
\hline & $\begin{array}{l}\text { Group I } \\
\text { No fluid }\end{array}$ & $\begin{array}{l}\text { Group } 1 / \\
3 \mathrm{ml}, 1.5 \% \\
\text { lidocaine }\end{array}$ & $\begin{array}{l}\text { Group III } \\
3 \mathrm{ml} \text {, normal } \\
\text { saline }\end{array}$ \\
\hline Number of patients & 77 & 68 & 55 \\
\hline Primipara & 42 & 43 & 33 \\
\hline Height $-\mathrm{cm}$ & $162 \pm 08$ & $162 \pm 06$ & $164 \pm 05$ \\
\hline Weight - kg & $74.1 \pm 10$ & $75.0 \pm 10$ & $75.7 \pm 09$ \\
\hline Gestational age (wk) & $40.0 \pm 1.2$ & $40.2 \pm 2.3$ & $40.1 \pm 1.3$ \\
\hline Cervical dilatation - $\mathrm{cm}$ & $4.0 \pm 1.9$ & $4.1 \pm 1.8$ & $3.9 \pm 1.6$ \\
\hline
\end{tabular}

Mean \pm SD

unable to flex knees, but with free movement of feet; or (4) complete if no movement was possible. ${ }^{5}$ Since the degree of motor block was often asymetrical, both legs were assessed and the greatest degree of motor block in either leg was used in further analysis.

All patients were interviewed within $24 \mathrm{hr}$ of delivery in order to detect subjective or objective evidence of neurological deficit.

Demographic data were compared using one-way analysis of variance. The remaining data were analyzed for statistical significance $(P<0.05)$ using Chi-square analysis (with the Yates correction for continuity for $2 \times 2$ matrices) and the Bonferroni correction for multiple comparisons.

Sample size was selected on the basis of the incidence of paraesthesiae in the "dry" group (Group I) determined to be 49 per cent in a previous study. ${ }^{3}$ Using a total sample size of 200, a difference of 20 per cent in the incidence of parasthesia in Group II or Group III compared with Group 1 would be detected with a beta error of 0.8 and an alpha error of 0.05 .

\section{Results}

There were no differences among the groups with respect to the height, weight, parity, gestational age or cervical dilatation at the time of epidural catheter insertion (Table I). There was no statistically significant difference in the incidence of paraesthesiae, involuntary movement or blood in the catheter. For each technique described, the catheter was inserted easily in a similar proportion of patients (Table II).

The pain relief was rated as satisfactory or better by 85 per cent of patients in Group I, 82 per cent in Group II and 79 per cent in Group III. All patients had satisfactory analgesia after an additional dose was given. There was free movement of the legs and feet in 96 per cent of patients in Group I, 94 per cent in Group II and 88 per cent in Group III. These differences were not significant.

There was one patient in Group I who had pain radiating into the right calf at $24 \mathrm{hr}$ but not $48 \mathrm{hr}$ after 
TABLE II Complications of catheter insertion percentage of patients

\begin{tabular}{|c|c|c|c|c|}
\hline & $\begin{array}{l}\text { Group I } \\
\text { No fluid }\end{array}$ & $\begin{array}{l}\text { Group II } \\
3 \mathrm{ml} .1 .5 \% \\
\text { lidocaine }\end{array}$ & $\begin{array}{l}\text { Group III } \\
3 \text { ml, normal } \\
\text { saline }\end{array}$ & $P$ \\
\hline Blood in catheter & 10 & 10 & 9 & $\mathrm{~N} / \mathrm{S}$ \\
\hline Paraesthesiac & 56 & 50 & 53 & $\mathrm{~N} / \mathrm{S}$ \\
\hline Involuntary movement & 18 & 18 & 20 & $N / S$ \\
\hline Threaded easily & 87 & 93 & 76 & $\mathrm{~N} / \mathrm{S}$ \\
\hline
\end{tabular}

delivery. She had experienced a paraesthesia, on the same side, with catheter insertion and was delivered by a mid-vacuum extraction.

\section{Discussion}

Insertion of the epidural catheter may be associated with blood vessel trauma or nerve root irritation. The incidence of parasthesiae and blood vessel trauma are up to 50 per cent and ten per cent respectively. ${ }^{2-4}$ The incidence of these two common complications remained the same in this study. Several factors may influence the incidence of paraesthesiae or blood vessel trauma. These include the material from which the catheter is made, whether epidural puncture is made precisely in the midline and the length of catheter advanced into the epidural space. ${ }^{6-8}$

The injection of air or fluid through the needle influences the incidence of these complications. The injection of $10 \mathrm{ml}$ of air, through the needle prior to epidural catheter insertion, has been shown to reduce the incidence of paraesthesiae from 49 to 29 per cent and the incidence of vessel puncture from 5.8 to 1.6 per cent. ${ }^{9}$ The injection of air has several disadvantages. The incidence of air embolus may be increased. ${ }^{10}$ Air bubbles, demonstrated radiographically, may persist in the epidural space leading to poor analgesia in some segments. "I Neurological deficit has been caused by large volumes of epidural air. ${ }^{12}$ The injection of $10 \mathrm{ml}$ of local anaesthetic administered through the needle prior to catheter insertion has been shown to decrease the incidence of blood vessel trauma from nine to three per cent. ${ }^{13}$ This technique, however, would result in total spinal anaesthesia if accidentally injected intrathecally or local anaesthetic toxicity if injected intravascularly. Furthermore, the epidural catheter would be untested until the first top-up dose. Preservative-free saline could also be used to expand the epidural space. In this study it was not found to alter the incidence of either blood vessel trauma or paraesthesiae. Larger volumes of saline might be used but may reduce the effectiveness of the block by diluting the local anaesthetic.

In some patients, injection of a small amount of fluid through the epidural needle may help the anaesthetist to identify the epidural space when loss of resistance to air is doubtful. This is done either by demonstrating loss of resistance to the injection of fluid or by noting lack of compression of an air bubble in the syringe. This study did not specifically address the efficacy of injecting fluid in this manner, although the number of satisfactory epidural anaesthetics was not altered by the injection of fluid.

There may be disadvantages associated with the injection of fluid through the needle prior to insertion of an epidural catheter. The significance of clear fluid retum from the needle hub may be difficult to interpret. The risk of dural puncture may be increased if the needle is advanced during injection. ${ }^{14}$ The effectiveness of a second "test dose" through the catheter in detecting intrathecal injection has yet to be assessed in the presence of epidural local anaesthetic previously injected through the needle.

This study did not find any differences in the occurrence of minor complications during the insertion of an epidural catheter using the "dry" technique, $3 \mathrm{ml}, 1.5$ per cent lidocaine or $3 \mathrm{ml}$, normal saline. The quality of pain relief was similar in all groups. Although a previous study by one of the authors ${ }^{3}$ had shown a reduction in the incidence of paraesthesiae when local anaesthetic was injected through the needle, the depth of catheter insertion was not controlled, nor was there an independent observer to record the events. These factors could explain why the results were different from those reported in the current study.

Long-term neurological deficit following labour and delivery without regional anaesthesia has an incidence of 1:2600 to $1: 6400 .^{15}$ There are several mechanisms by which this can occur. The cord or nerve roots may be compressed by a prolapsed intervertebral disc. Peripheral nerves may be injured by compression where they cross the pelvic brim (e.g., lumbosacral trunk, femoral nerve, lateral femoral cutaneous nerve). ${ }^{8}$ The common peroneal nerve may be damaged by faulty leg positioning in stimups. Nerve damage caused by the epidural catheter may also occur but this is rare compared to obstetrical causes and is difficult to diagnose. ${ }^{16}$

Although paraesthesiae on catheter insertion is common, persisting neurological deficit is very rare. ${ }^{17}$ None of the patients in our study who experienced paraesthesiae had permanent neurological symptoms. Whether the persistent pain experienced by one of our patients was due to the epidural catheter or to obstetrical factors such as prolonged labour, midvacuum extraction, malposition or a large fetus cannot be determined. A much larger study would be necessary to exclude the association between paraesthesiae on insertion of the epidural catheter and neurological deficit because of the low incidence of this complication. 
In conclusion, there was no advantage to injection of 3 ml fluid into the epidural space prior to catheter insertion. The injection of local anaesthetic or normal saline did not alter the occurrence of paraesthesiae or blood vessel trauma or improve ease of catheter insertion. Injection of small amounts of fluid should be reserved for those cases where this may assist in identification of the epidural space.

\section{References}

1 Bromage PR. Epidural Analgesia. Philadelphia: W.B. Saunders, 1978; 218.

2 Rolbin SH, Hew E. A comparison of two types of epidural catheters. Can J Anaesth 1987, 34: 459-61.

3 Halpern SH, Onayami A, Swartz J, Rosaeg O. Does an epidural test dose prevent complications of epidural catheter insertion? Anesth Analg 1987; 66: S77.

4 Rolbin SH, Relle A, Hew EM. Hyperventilation does not affect the incidence of parasthesiae and blood vessel cannulation during epidural cathetcr insertion. Can Anaesth Soc J 1985; 32: 568.

5 Bromage PR. Epidural Analgesia. Philadelphia: W.B. Saunders, 1978, 144.

6 Abouleish E. Pain Control in Obstetrics. Philadelphia: J.B. Lippincott, 1977, 262-3.

7 Moore DC. Regional Block. Springfield: Charles C. Thomas, 1965, 437.

8 Bromage PR. Neurologic Complications of Regional Anaesthesia in Ancsthesia for Obstetrics, 2nd cd., Shnider SM, Levinson G (Eds.). Baltimore: Williams and Wilkins, 1987, 316-24.

9 Philip BK. Effect of epidural air injection on catheter complications. Reg Anesthesia, 1985; 10: 21-3.

10 Naulty SJ, Ostheimer GW, Datta S, Knapp R, Weiss $J B$. Incidence of venous air embolism during epidural catheter insertion. Anesthesiology 1982; 57: 410-2.

11 Dalens B, Bazin JE, Haberer JP. Epidural bubbles as a cause of incomplete analgesia during epidural anesthesia. Anesth Analg 1987; 66: 679-83.

12 Kennedy TM, Ullman DA, Harte FA, Saberski LR. Greenhouse $B B$. Lumbar root compression secondary to epidural air. Anesth Analg 1988; 66: 1184-6.

13 Verniquet AJW. Vessel puncture with epidural catheters. Anaesthesia 1980; 35: 660-2.
14 Crawford JS. Obstetric Analgesia and Anaesthesia, 2nd ed. In: Current Reviews in Obstetrics and Gynccology, 1984. Edinburgh: Churchill Livingstonc, 69.

15 Hill EC. Matemal obstetric paralysis. Am J Obstet Gynecol 1962; 83: 1452-60.

16 Usubiaga JE. Neurological complications following epidural anesthesia. Int Anesthesiol Clin 1975; 13: 33-7.

17 Ong BY, Cohen MM, Esmail A, Cumming M, Kozody $R$, Palahnuik RJ. Paraesthesia and motor dysfunction after labour and delivery. Anesth Analg 1987; 66: 18-22. 